\title{
MENGGALI POTENSI BUDAYA MAJA LABO DAHU SEBAGAI BASIS PENDIDIKAN ETIKA DAN MORAL DI SEKOLAH
}

\author{
Amiruddin \\ Mahasiswa Pascasarjana Universitas Negeri Malang \\ amiruddinbima@gmail.com
}

\begin{abstract}
Abstrak
Maja labo dahumerupakan sistem nilai budaya ideal yang bersifat abstrak, sebagai pandangan hidup yang dijadikan pedoman dalam berfikir, bertindak dan berkomunikasi dalam aktivitas kehidupan masyarakat Bima. Makna budaya maja labo dahu juga bersifat simbolis yang mengandung arti yang luas. Orang Bima di pedalaman misalnya mempunyai pandangan bahwa maja labo dahu berartidou (manusia) yang mempunyai sifat-sifat yang berbeda dengan binatang. Walaupun douitu selain memiliki sifatsifat kemanusiaan, juga memiliki sifat-sifat kebinatangan. Menurut pandangan mereka, manusia dapat membedakan yang baik dan yang buruk, maka orang yang dapat mengaplikasikan sifat-sifat kemanusiaannya itulah yang disebut dou (manusia) atau yang memiliki maja labo dahu. Dengan analogi sederhana bahwa setiap orang yang berhasil dalam pendidikannya, pekerjaannya atau usahanya disebut telah menjadi manusia karena diangga telah nilai implementasi budaya maja labo dahu dalam tatanan sosial kehiupannya.
\end{abstract}

Kata Kunci : Etika, Moral, Maja Labo Dahu

\section{Pendahuluan}

$\mathrm{P}$ ada millennium ketiga, bangsa Indonesia dideskripsikan sebagai masyarakat yang antara satu dengan yang lainnya saling bermusuhan. Hal ini sudah digambarkan oleh Allah Swt dalam firmannya Surat Ali Imran:103, sebagai kehidupan yang terlibat dalam wujud saling bermusuhan (idz kuntum a'da'a) ayat ini menegaskan suatu wujud kehidupan yang berada pada ancaman kehancuran. Abdurrahman Ibn Amru As-Sulami meriwayatkan bahwa bahwa ia mendengar AlIrbadh ibn Sariyah berkata,

"Rasulullah SAW memberi nasihat kepada kami yang membuat mata menangis dan menggetarkan hati.Kami bertanya, Hai Rasul, sesungguhnya ini nasihat orang yang akan berpisah, lalu apa pesan Anda pada kami?"Jawab beliau, “Kutinggalkan kalian dengan Hujjah yang jelas.Malamnya seperti siang.Tak ada yang tersesat setelahku kecuali orang yang binasa. Siapa diantara kalian hidup 
setelahku.Ia akan melihat perselisihan yang banyak.Kalian harus memegang teguh Sunnahku dan Sunnah Khulafur Rasyidin yang mendapat petunjuk.Gigitlah Sunnahku itu dengan gerahanmu.Kalian harus taat walapun (pemimpin kalian) seorang budak Habsyi.Sesungguhnya seorang mukmin itu seperti unta yang di ikat hidungnya yang bila di ikat, ia menurut." Umar Sulaiman (Karyono, 2013).

Hidup adalah sebuah misteri, sebab apa yang terjadi selanjutnya tentang kehidupan pasti tak dapat mengetahuinya melainkan kita hanya berusaha dan berdoa kepada sang kholik supaya kita benar-benar menjadi manusia yang berguna dan bermanfaat untuk orang lain. Problematikayang terjadi saat ini melanda dou labo dana mbojoseperti meningkatnya potensi konflik diberbagai kota dan kabupaten yang ada di Bima (dana mbojo)merupakan tanda-tanda bahwa Bima (Mbojo) sudah terjadi krisis nilai dan moralitas pada diri manusia, tindakan amoral yang secara terbuka di mulai dari anak-anak, remaja, dewasa bahkan yang lebih ironisnya lagi sebagian orang tua sudah tak memiliki nilai dan moralitas serta etika tentang bagaimana mendidik anaknya.

Problematika seperti inilah yang menandakan bahwa sebagian dou labo dana mbojo sudah tak lagi memiliki nilai dan moralitasnya. Kemudian di bidang sosial banyak muncul berbagai masalah, tindakan criminal sering terjadi dan pelanggaran norma-norma bisa dilakukan oleh berbagai oknum Stacholder-Stacholder dilingkungan pemerintahan, anggota masyarakat dan lebih memprihatinkan lagi adalah tindakan penyalahgunaan narkoba oleh anak-anak sekolah, mahasiswa serta masyarakatnya. Memunculnya berbagai masalah turut menjustifikasi posisi daerah dan masyrakat Bima identik dikenal dengan daerah yang rawan dengan konflik sosial, inilah yang dinamakan krisis nilai dan moralitas doulabo dana mbojo. Sedangkan dilihat dariprespektif psikologi perkembangan, dunia nampak semakin tua, manusia semakin cerdas, pengetahuan semakin dewasa, dan teknologi pun semakin canggih.Namun di balik semua itu, apakah kehidupan menjadi semakin baik, semakin nyaman, dansemakin sejahtera, baik secara lahiriah maupun bathiniah.Bahkan sebaliknya kehidupan nampaknya semakin mundur dan terpuruk, reformasi yang "gebablasan", korupsisemakin merajalela, dan lain sebagainya. Kondisis inilah yang dinamakan dengan krisis Multidimensi yang dirasakan oleh manusia termasuk yang dialami oleh masyarakat Bima (dou mbojo). 


\section{Maja Labo Dahu Persepektif Tentang Etika Sosial dan Norma}

\section{Etika Sosial}

Krisis moral ini terjadi karena sendi-sendi beretika sosial dan menjaga nilai-nilai agama sudah dilupakan, jika kita membandingkan beberapa penggalan masa yang berlangsung, ada beberapa kesenjangan yang terjadi khususnya menyangkut etika sosial dan nilai-nilai moral yang dahulu kala merupakan kebanggaan dou labo dana mbojo yang dikenal dengan motto maja labo dahu. Sekarang, baik suka ataupun tidak suka, kita harus mengakui bahwa telah terjadi pergeseran dalam etika dan moral dou labo dana mbojo yang disebabkan banyaknya nilai Amoral yang terjadi sehingga motto tersebut sudah tak lagi menjadi kebanggaan orang Bima (Dana Mbojo) yang ada hanyalah tinggal namanya saja sebagai simbol sehingga tidak mampu mengejewantahkan dalam kehidupan sehari-hari.

Indikasi runtuhnya nilai dan moralitas ini gampang saja terjadi.Karena perilaku tawuran dari mulai pelajar, mahasiswa, masyarakat sampai para wakil rakyat sudah menjadi pemandangan sehari-hari. Perilaku yang menyedihkan ini sepertinya telah melampaui hukum adat dan budaya dou Mbojo yang dikenal dengan budaya maja labo dahu. Tidak ada lagi rasa pengagungan terhadap sikap menghargai orang yang lebih dewasa maka tanda bagi cacatnya etika itu sesungguhnya benar terjadi di daerah kita tercinta.

Krisis ini terjadi karena sendi-sendi beretika sosial dan menjaga nilai-nilai agama sudah dilupakan.Tidak ada lagi kepedulian bagi generasi muda dalam hal beragama dan berbudaya sesuai tuntutan budaya setempat.Ini dibuktikan dengan makin maraknya pelanggaran etika sosial bahkan jatuhnya nilai moralitas para generasi tanpa bisa dicegah oleh Orang Tua, Guru, Ulama dan Tokoh Cendekiawan lainnya. Akhirnya mari kita cegah tindakan perilaku generasi dari kecacatan etika sosial dan nilai moralitas yang tidak sesuai dengan budaya kita dengan cara saling nasehat-menasehati, saling hargai-menghargai,orang tua menghargai yang kecil-yang kecil menghargai yang tua, guru menghargai siswanya, siswa menghargai gurunya, Para Pejabat menghargai bawahannya dan bawahan menghargai atasanya, sehingga akan tercipta masyarakat yang saling menjaga dan menghargai sesamanya.Ketika berbicara tentang etika sosial, maka tidak bisa dilepaskan dari masalah etika terhadap lingkungan.Lingkungan dalam arti sebuah organisme yang hidup berinteraksi secara lekat dengan 
keberadaan setiap mahluk di bumi ini.Pengembangan etika lingkungan hidup diperlukan untuk mengendalikan perubahan secara mendasar dari pandangan kosmologi yang menumbuhkan sikap hormat dan bersahabat dengan alam lingkungan (J. Sudriyanto, 1992:13).

Para tokoh pendidikan di dunia Barat telah melakukan perdebatan panjang seputar persoalan pendidikan dan termasuk lingkungan yang dapat mempengaruhi etika manusia terhadap lingkungan seperti Aliran Empirisme yang dipelopori oleh Jhon Lock (1632-1704) dengan teori "Tabularasa". Teori ini berpendapat bahwa manusia dilahirkan dengan jiwa yang kosong.Manusia dilahirkan tanpa potensi dasar apapun sehingga jiwanya diibaratkan seperti meja lilin atau kertas putih yang bersih tanpa noda.Pendidikanlah yang sangat berperandalam membentuk dan mewarnai jiwa manusia. Apabila manusia dalam pertumbuhan dan perkembangannya menerima pendidikan yang baik, maka ia akan tumbuh menjadi manusia yang bermutu. Sebaliknya, apabila dalam pertumbuhannya ia menerima pendidikan-pendidikan yang buruk, maka ia akan tumbuh menjadi manusia yang buruk. Paham ini menghendaki bahwa pertumbuhan dan perkembangan hidup manusia ditentukan sepenuhnya oleh factor-faktor pengalaman yang berada di luar diri manusia, baik disengaja yang didesain melalui pendidikan informal, non formal dan alam sekitar.

Boff (Chan, 2003) mengusulkan lima jenis etika yang dianggap sebagai sangat mendesak di dunia saat ini : (1) Etika ini menyerukan umat manusia untuk saling melihat antara satu sama lain (dalam pengertian positif), setiap orang merasa bertanggungjawab terhadap kondisi orang lain sebagai temannya. Perhatian yang dia berikan kepada orang lain bukan hanya sekedar pemanis bibir saja tetapi rasa simpati yang sesungguhnya dan tindakan nyata yang menerangi penderitaan dan duka cita kawannya sesama manusia. (2) Etika solidaritas : etika ini ditandai oleh sikap solidaritas sosial terhadap siapa saja yang dililit kesulitan. Masyarakat mempunyai tanggungjawab moral untuk saling membantu dan berhubungan dengan orang-orang yang sedang mengalami kesulitan. (3) Etika tanggungjawab : etika ini mengutamakan sikap tanggungjawab setiap orang terhadap pemikiran, ucapan, dan tingkah laku dalam kehidupan sehari-hari. Sikap ini menuntut agar setiap orang betul-betul berpikir sebelum menulis, berbicara atau bertindak sebab setiap tindakan memerlukan tanggungjawab dihadapan orang lain dan tuhan. (4) Etika berdialog : etika ini di mulai dengan dialog yang 
hidup, tulus dan ikhlas. Apa yang difokuskan dalam dialog sekarang adalah kehidupan, ketulusan, kebenaran, dan kebaikan umat manusia yang bertanggungjawab terhadap kehidupan mereka. Dan (5) Etika suci : etika ini mencakup dan dapat diterima oleh seluruh pihak sebab dia didahului oleh nilai-nilai kebaikan secara universal yang dapat diterima oleh semua orang dalam setiap kondisi. Etika ini tidak saja dimonopoli oleh satu kelompok, tapi sesungguhnya juga dimiliki oleh seluruh kelompok.Tidak seorangpun yang dapat menyatakan bahwa merekalah satu-satunya yang memiliki etika ini.Pada dasarnya kelima etika ini menekankan dimensi sosial dari kehidupan umat manusia.Individu dapat menjadi dirinya disebabkan pengaruh ketergantungannya dengan temannya sesama umat manusia.Sekarang tidak perlu (bagi kita) untuk mendambakan budaya tunggal, agama tunggal, dan masyarakat monolitik secara menyeluruh. Oleh karena itu, nilai-nilai sosial, seperti solidaritas, tanggungjawab, dialog yang tulus dan keterbukaan bagi semua pihak merupakan hal yang sangat penting dalam masyarakat.

\section{Norma}

Rumusan tentang norma dan nilai pada dasarnya sama. Nilai sosial adalah suatu perbuatan atau tindakan yang oleh masyarakat dianggap baik. Nilai sosial dalam setiap masyarakat tidak selalu sama, karena nilai di masyarakat tertentu dianggap baik tapi dapat dianggap tidak baik dimasyarakat lain. Nilai ini dibagi beberapa bagian yaitu: Nilai material artinya segala sesuatu yang berguna bagi manusia. Nilai vital artinya segala sesuatu yang berguna bagi manusia untuk dapat melakukan aktivitas atau kegiatan.Nilai kerohanian artinya segala sesuatu yang berguna bagi rohani manusia.

Selanjutnya norma sosial adalah suatu petunjuk hidup yang berisi larangan maupun perintah.Yang membedakan nilai dan norma adalah nilai merupakan sesuatu yang baik, diinginkan, dicita-citakan dan dipentingkan oleh masyarakat. Sedangkan norma adalah kaidah atau pedoman, aturan berperilaku untuk mewujudkan keinginan dan cita-cita tersebut, atau boleh dikatakan nilai adalah pola yang diinginkan sedangkan norma adalah pedomana atau cara-cara untuk mencapai nilai tersebut.Norma merupakan faktor perilaku dalam kelompok tertentu yang memungkinkan seseorang untuk menentukan terlebih dahulu bagaimana tindakan akan dinilai orang lain. Norma merupakan aturan, pedoman, atau petunjuk hidup dengan sanksi-sanksi untuk mendorong seseorang, kelompok, dan masyarakat mencapai dan mewujudkan nilai- 
nilai sosial.Norma-norma merupakan aturan yang tumbuh dan hidup dalam masyarakat sebagai unsur pengikat dan pengendali manusia dalam hidup masyarakat.

\section{Nilai Moral Budaya Maja Labo Dahu dalam Perspektif Dou Mbojo}

Maja Labo Dahu merupakan system nilai budaya ideal yang bersifat abstrak, artinya maja labo dahu merupakan pandangan hidup yang dijadikan pedoman dalam berfikir, bertindak dan berkomunikasi di masyarakat.Maja labo dahu itu bersifat abstrak, karena merupakan system nilai budaya yang ideal dan pandangan hidup. Maja labo dahu itu tampak dalam prilaku masyarakat Bima. Maja labo dahu lebih bersifat simbolis yang mengandung arti yang luas. Orang Bima di pedalaman misalnya, mempunyai pandangan bahwa maja labo dahu berartidou (manusia) yang mempunyai sifat-sifat yang berbeda dengan binatang. Walaupun douitu selain memiliki sifat-sifat kemanusiaan, juga memiliki sifat-sifat kebinatangan.

Menurut pandangan mereka, karena manusia dapat membedakan yang baik dan yang buruk, maka orang yang dapat mengaplikasikan sifat-sifat kemanusiaannya itulah yang disebut $d o u$ (manusia) atau yang memiliki maja labo dahu.Misalnya orang yang berhasil dalam pendidikannya, pekerjaannya atau usahanya disebut telah menjadi manusia.Maja labo dahu, suatu ungkapan filosofis yang mengandung makna yang luas. Bila ungkapan tersebut diartikan secara harfiah maja labo dahu berarti malu dengan takut hal ini akan memberikan arti dan dampak psikologis yang tidak diinginkan oleh ungkapan itu sendiri. Pengertian dan makna semacam itu hanya akan mengerdilkan pikiran, mematikan inisiatif serta mengeringkan cita-cita untuk melangkah ke depan meraih harapan yang diidamkan.Maja labo dahu merupakan pandangan hidup masyarakay Bimayang artinya malu dan takut.Malu berbuat tidak baik dan takut kepada Allah, dan makanya juga dapat diterjemahkan ke dalam makna esensial Habbluminannas dan habluminallah.Ungkapan Maja Labo Dahu merupakan symbol yang diucapkan dengan tiga kata yang senantiasa aplikasi keduanya tidak dapat lepas dan dipisahkan satu dengan yang lainnya, karena saling memberi pengaruh terhadap terbentuknya sikap positif. Oleh karena itu 
disebut pula sebagai ungkapan filosofis yang mengandung makna yang luas. Demikian pula suatu gambaran aktual tentang Maja Labo Dahu, dari tokoh budayawan Bima, Bapak M. Hilir Ismail (dalam Muhammadiyah) menuturkan sebagai berikut:

Bagi orang Bima merupakan norma adat yang harus dipegang sebagai "Fu'u mori ro woko"(tiang atau pedoman hidup). maja labo dahuadalah sIstem nilai yang sarat dengan nilai Iman dan Takwa, kebajikan, martabat, dan harga diri yang selalu menjadi rujukan dalam bertindak.Orang yang tidak mematuhi orangtuanya termasuk orang yang kurang Maja Labo Dahunya.Dengan begitu, Maja Labo Dahu menjadi bagian terdalam dalam diri orang Bima (Dou Mbozo) yang dijunjung tinggi dan perlu dipertahankan keberadaannya.

Salah satu upaya yang dilakukan oleh raja-raja Bima dan tokohtokoh masyarakat dahulu agar keberadaan maja labo dahudi masyarakat Bima (dana mbojo) tetap menjadi tuntunan atau pedoman dalam berfikir, bertindak, dan berkomunikasi adalah mengaktualisasikan pesan-pesan moral ke dalam bentuk syair (pantun).Syair merupakan nasehat, ajaran, amanat atau wasiat yang disampaikan secara lisan atau tulisan kepada warganya secara turun temurun.Itulah sebabnya syair dipelihara dan dihormati untuk dijadikan kaedah hidup dalam masyarakat Bima.

\section{SIMPULAN}

Dari uraian di atas penulis dapat menyimpulkan bahwa maja labo dahu adalah sebuah ungkapan yang sangat luas, dan terdapat di dalamnya ada nilai-nilai pendidikan, spiritual, dan memiliki daya tarik yang kuat untuk dijadikan pedoman untuk kehidupan sosial kemasyarakatan dalam mencapai titik puncak kebahagiaan hidup, baik di Dunia maupun di Akhirat. Apabila motto maja labo dahu ini kita tinggalkan dan kita abaikan dalam kehidupan kita dan kemudian hanya sebagai symbol atau ungkapan saja dan tidak diaplikasikannya, maka kita akan lebih dekat dengan kemungkaran dan tidak heran kita melihat anak-anak, remaja, dewasa dan orang tua akan mengadopsi modernisme (westernisme), kendatipun tidak secara total yang dilakukan oleh masyarakat Bima (Dou Mbojo). 


\section{DAFTAR PUSTAKA}

Arqom, A. 2010.Menciptakan Keajaiban Hidup.JIP BOOKS. Surabaya. Djamal, 2003.Konflik Komunal di Indonesia Saat ini.IndonesiaNetherlands Cooperation in Islamic Studies (INIS). Universiteit Leiden.

Fakhrudin.A. Al-Qur'an Tafsir Per Kata Tajwid Kode Angka. Kalim.Banten.

Karyono dkk, 2013.Bimbingan dan Konseling (Pendekatan Qur'ani). CV. Nurani. Wangunsari.

Lickona, T. 2013. Educating For Character. Remaja Rosdakarya. Jakarta.

Muhamadiah, 2005.Nilai-Nilai Syair Budaya Masyarakat Bima Dan Implikasinya Bagi Pengembangan Materi Bimbingan Pribadi dan Sosial. Jurnal Bimbingan dan Konseling STKIP Bima.

Sultoni. 2014. Meneladani Kepemimpinan Rasulullah SAW. Buletin ArRaudhah. Universitas Negeri Malang.

Sutoyo, A. 2013.Bimbingan dan Konseling Islami (Teori dan Praktik). Pustaka Pelajar. Yogyakarta.

Thoib, I. 2008. Wacana Baru Pendidikan, Meretas Filsafat Pendidikan Islam. Genta Press. Yogyakarta. 